\title{
Synthesis of $\alpha, \beta$-unsaturated esters via a chemo-enzymatic chain elongation approach by combining carboxylic acid reduction and Wittig reaction
}

\author{
Yitao Duan, Peiyuan Yao, Yuncheng Du, Jinhui Feng, Qiaqing Wu* and Dunming Zhu*
}

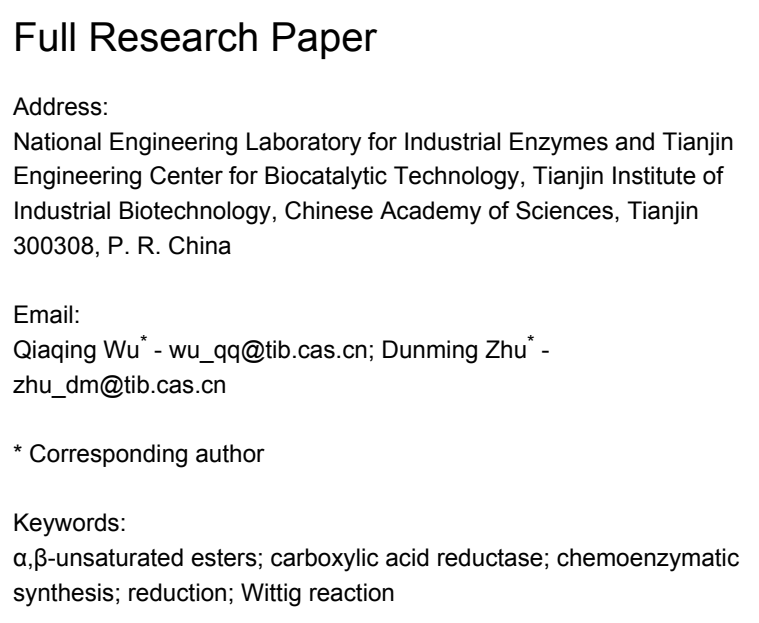

Beilstein J. Org. Chem. 2015, 11, 2245-2251.

doi:10.3762/bjoc.11.243

Received: 20 August 2015

Accepted: 28 October 2015

Published: 19 November 2015

This article is part of the Thematic Series "Sustainable catalysis".

Guest Editor: N. Turner

() 2015 Duan et al; licensee Beilstein-Institut.

License and terms: see end of document.

\begin{abstract}
$\alpha, \beta$-Unsaturated esters are versatile building blocks for organic synthesis and of significant importance for industrial applications. A great variety of synthetic methods have been developed, and quite a number of them use aldehydes as precursors. Herein we report a chemo-enzymatic chain elongation approach to access $\alpha, \beta$-unsaturated esters by combining an enzymatic carboxylic acid reduction and Wittig reaction. Recently, we have found that Mycobacterium sp. was able to reduce phenylacetic acid (1a) to 2-phenyl-1ethanol (1c) and two sequences in the Mycobacterium sp. genome had high identity with the carboxylic acid reductase (CAR) gene from Nocardia iowensis. These two putative CAR genes were cloned, overexpressed in E. coli and one of two proteins could reduce 1a. The recombinant CAR was purified and characterized. The enzyme exhibited high activity toward a variety of aromatic and aliphatic carboxylic acids, including ibuprofen. The Mycobacterium CAR catalyzed carboxylic acid reduction to give aldehydes, followed by a Wittig reaction to afford the products $\alpha, \beta$-unsaturated esters with extension of two carbon atoms, demonstrating a new chemo-enzymatic method for the synthesis of these important compounds.
\end{abstract}

\section{Introduction}

$\alpha, \beta$-Unsaturated esters are versatile building blocks for organic synthesis and of significant importance for industrial applications [1-13]. A great variety of synthetic methods have been developed to access $\alpha, \beta$-unsaturated esters [14-24]. One popular approach is the Wittig reaction which produces $\alpha, \beta$-unsaturated esters with two more carbon atoms [25]. While fatty acids are abundant from natural resources, aromatic carboxylic acids could be prepared by the degradation of lignin, an unused and 
abundant component of biomass, although the effective methods for the degradation of lignin need to be developed. These carboxylic acids could be reduced to their corresponding aldehydes, which can be used as starting materials for Wittig reaction. The combination of carboxylic acid reduction and Wittig reaction would offer a new approach for the production of bio-based $\alpha, \beta$-unsaturated esters. However, the conventional chemical methods for the carboxylic acid reduction require strong reducing reagents such as metal hydrides, posting operational danger and low selectivity. In addition, the conversion of $\mathrm{COOH}$ into $\mathrm{CHO}$ requires particular hydride reagents, to avoid the further reduction to primary alcohols [26]. On the contrary, enzymatic reduction of carboxylic acids proceeds under mild reaction conditions with high selectivity and tolerance of other functional groups [27,28]. Currently, only a few members of this interesting type of enzymes (CAR, E.C.1.2.1.30) have been biochemically characterized (Table 1). They possess similar consensus sequence characteristics and reaction mechanism (post-translational phosphopantetheinylation, ATP, $\mathrm{Mg}^{2+}$, and NADPH as cofactors) [27-30]. As such, we initiated the search for new carboxylic acid reductases and the exploration of their potential as biocatalysts for the efficient bioreduction of carboxylic acids. Herein we report a new CAR from Mycobacterium sp. (Mycobacterium CAR) and its application in a chemo-enzymatic chain elongation method for the preparation of $\alpha, \beta$-unsaturated esters by combining an enzymatic carboxylic acid reduction and Wittig reaction.

\section{Results and Discussion}

Nineteen actinomycete strains available in our laboratory were screened for the carboxylic acid reductase activity using phenylacetic acid (1a) as the substrate by GC analysis of the products. Among them, Mycobacterium sp. was found to catalyse the reduction of 1a to 2-phenyl-1-ethanol (1c) with low conversion (Supporting Information File 1, Figure S1). The genome of Mycobacterium sp. strain was sequenced, and two gene sequences having $58 \%$ and $47 \%$ protein sequence identity with the NiCAR [30] (accession number AAR91681.1) were found by local BLAST search (tblastn) (Supporting Information
File 1, Figure S2). These two genes were also found to have identical sequences with those (Gene ID 17912504 and Gene ID 17917114), respectively, in the genomic sequence of Mycobacterium neoaurum VKM Ac-1815D (accession no. CP006936) [34] by NCBI BLAST search (http://www.ncbi.nlm.nih.gov/ BLAST/).

Since PPTase from Mycobacterium sp. has not been identified, a known Nocardia PPTase (accession number ABI83656.1) was selected for the post-translational phosphopantetheinylation in the current study [27,28]. The gene (Gene ID 17912504) was cloned into pET30b(+) and expressed in E. coli. The recombinant enzyme (Mycobacterium CAR) showed carboxylic acid reductase activity toward 1a. The other gene (Gene ID 17917114) was cloned into pET28a(+) and expressed in E. coli. The gene was well expressed, but less fraction of soluble protein was obtained. The recombinant enzyme showed no carboxylic acid reductase activity toward 1a when it was tested under same conditions as the gene 17912504 after having been treated with the PPTase enzyme.

The His-tagged Mycobacterium CAR and His-PPTase were produced as soluble protein as described in Supporting Information File 1 and purified in one chromatographic step each using a HisTrap ${ }^{\mathrm{TM}}$ FF crude column (Supporting Information File 1, Figure S3). The molecular mass of His-CAR was estimated to be about $133 \mathrm{kDa}$ by gel filtration chromatography. Since its theoretical value is $125 \mathrm{kDa}$, this enzyme is a monomeric protein. This is consistent with NiCAR [31] and SrCAR [28]. The carboxylic acid reductase activity was hardly detected when apo-CAR was used in the reaction system (1a as substrate) or the reaction system did not contain $\mathrm{Mg}^{2+}$ (Supporting Information File 1, Table S2), indicating that post-translational phosphopantetheinylation and $\mathrm{Mg}^{2+}$ were necessary for this enzymatic reduction, similar to the observations for the reaction with the carboxylic acid reductases from Nocardia [29,35] and Segniliparus [28]. The optimal $\mathrm{pH}$ and temperature for the enzymatic reduction of 1a with Mycobacterium CAR were $\mathrm{pH} 9$ and $25^{\circ} \mathrm{C}$, respectively. The apparent $K_{\mathrm{m}}$ and catalytic efficien-

\begin{tabular}{llll}
\hline \multicolumn{2}{l}{ Table 1: Identified CARs (EC 1.2.1.30). } & References \\
\hline Identified CAR & Accession number & Origin & {$[30,31]$} \\
\hline NiCAR & \\
MsCAR & AAR91681.1 & Nocardia iowensis & {$[32]$} \\
SgCAR & WP_011855500.1 & Mycobacterium sp. JLS & {$[32]$} \\
MmCAR $^{\text {a }}$ & WP_012382217.1 & Streptomyces griseus subsp. griseus NBRC 13350 & {$[33]$} \\
SrCAR & WP_012393886.1 & Mycobacterium marinum M & {$[28]$} \\
Mycobacterium CAR & WP_013138593.1 & Segniliparus rotundus DSM 44985 & This work
\end{tabular}

${ }^{a}$ The protein was biochemically characterized and determined as a monomeric protein. ${ }^{\mathrm{b}}$ The protein was also purified from natural strain. 
cies $\left(k_{\mathrm{cat}} / K_{\mathrm{m}}\right)$ of Mycobacterium CAR toward benzoic acid (2a) (Supporting Information File 1, Table S1) were $1.75 \pm 0.16 \mathrm{mM}$ and $0.93 \mathrm{mM}^{-1} \cdot \mathrm{s}^{-1}$, respectively. They were lower than those for NiCAR [31], SrCAR [28] and MnCAR [33].

In order to explore the application potential of Mycobacterium CAR, its substrate specificity was examined with the purified enzyme. The results in Table 2 showed that a series of aromatic and aliphatic carboxylic acids were reduced to their corresponding aldehydes. For the aliphatic acids, the reduction of nonanoic acid (3a) and lauric acid (4a) resulted in higher yields than those of hexanoic acid (5a) and pentadecanoic acid (6a), indicating that Mycobacterium CAR prefers the mid-chain fatty acids over the short-chain and long-chain ones. Mycobacterium CAR also showed activity toward different carboxylic acids with aromatic ring at the end carbon atom. For example, 1a (75\% yield), 2a (94\% yield), 3-phenylpropanoic acid (7a, 48\% yield), and 4-phenylbutyric acid (8a) (64\% yield) were reduced to the corresponding aldehydes. In contrast to ortho- and metamethylbenzoic acid (9a and 10a), ortho-hydroxylbenzoic acid (11a) was obviously the poorer substrate than meta-counterpart (12a), suggesting that in this case the activity of Mycobacterium CAR might be strongly influenced by the electronic properties other than the steric factor of the ortho-group on the benzene ring. This enzyme was less active toward 2-methylhexanoic acid (13a) and 2-phenylpropionic acid (14a) than 5a

Table 2: Substrate specificity of Mycobacterium CAR $^{\mathrm{a}}$.

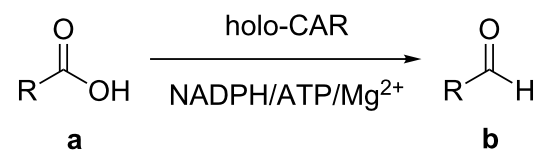<smiles>O=C(O)Cc1ccccc1</smiles><smiles>O=C(O)c1ccccc1</smiles><smiles>CC(C)(C)CC(=O)O</smiles><smiles>O=C(O)CCc1ccccc1</smiles><smiles>O=C(O)CCCc1ccccc1</smiles><smiles>O=C(O)c1ccc(I)cc1</smiles><smiles>O=C(O)c1ccc(O)cc1</smiles> 
Table 2: Substrate specificity of Mycobacterium CAR $^{\mathrm{a}}$. (continued)

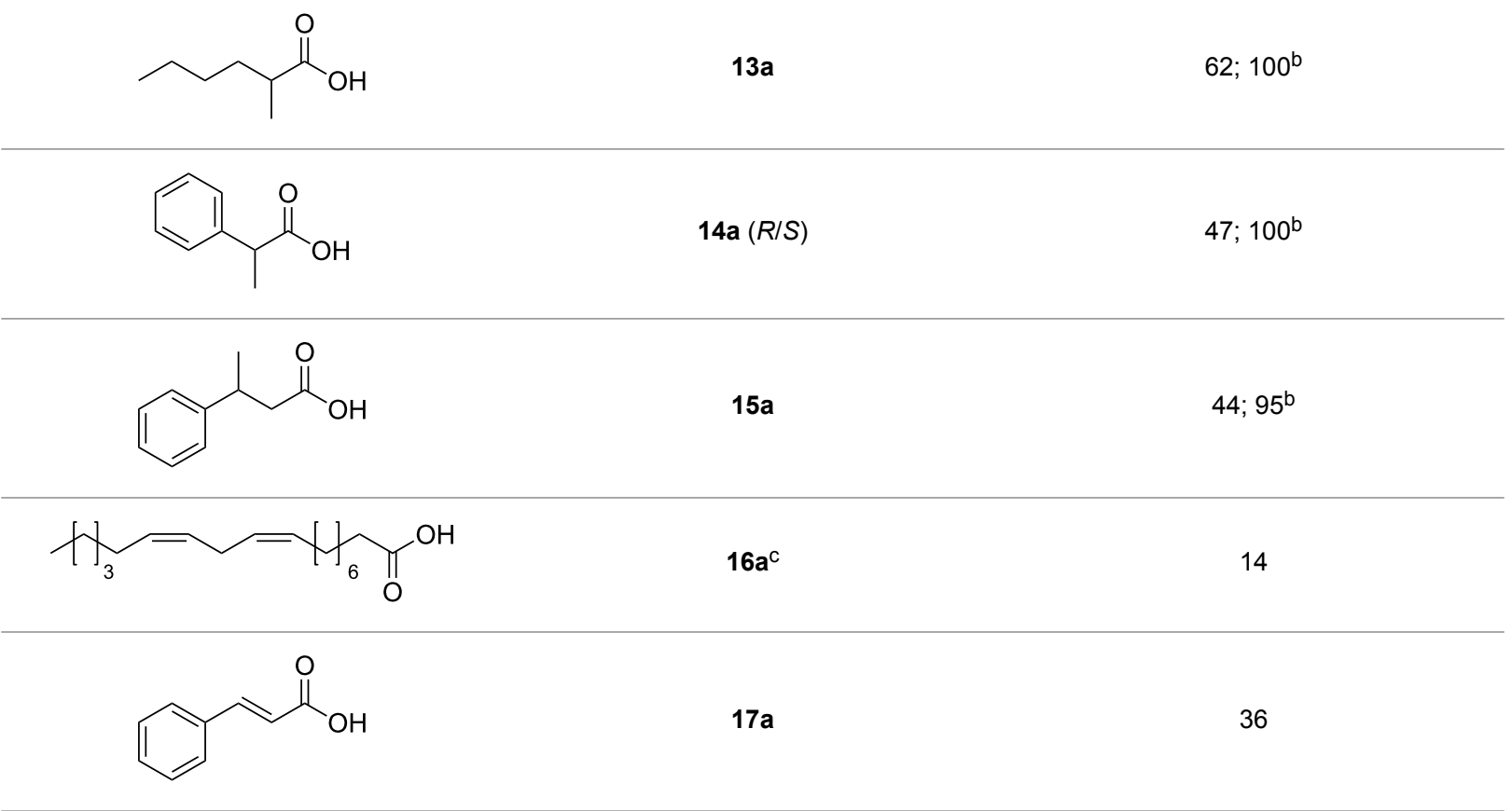

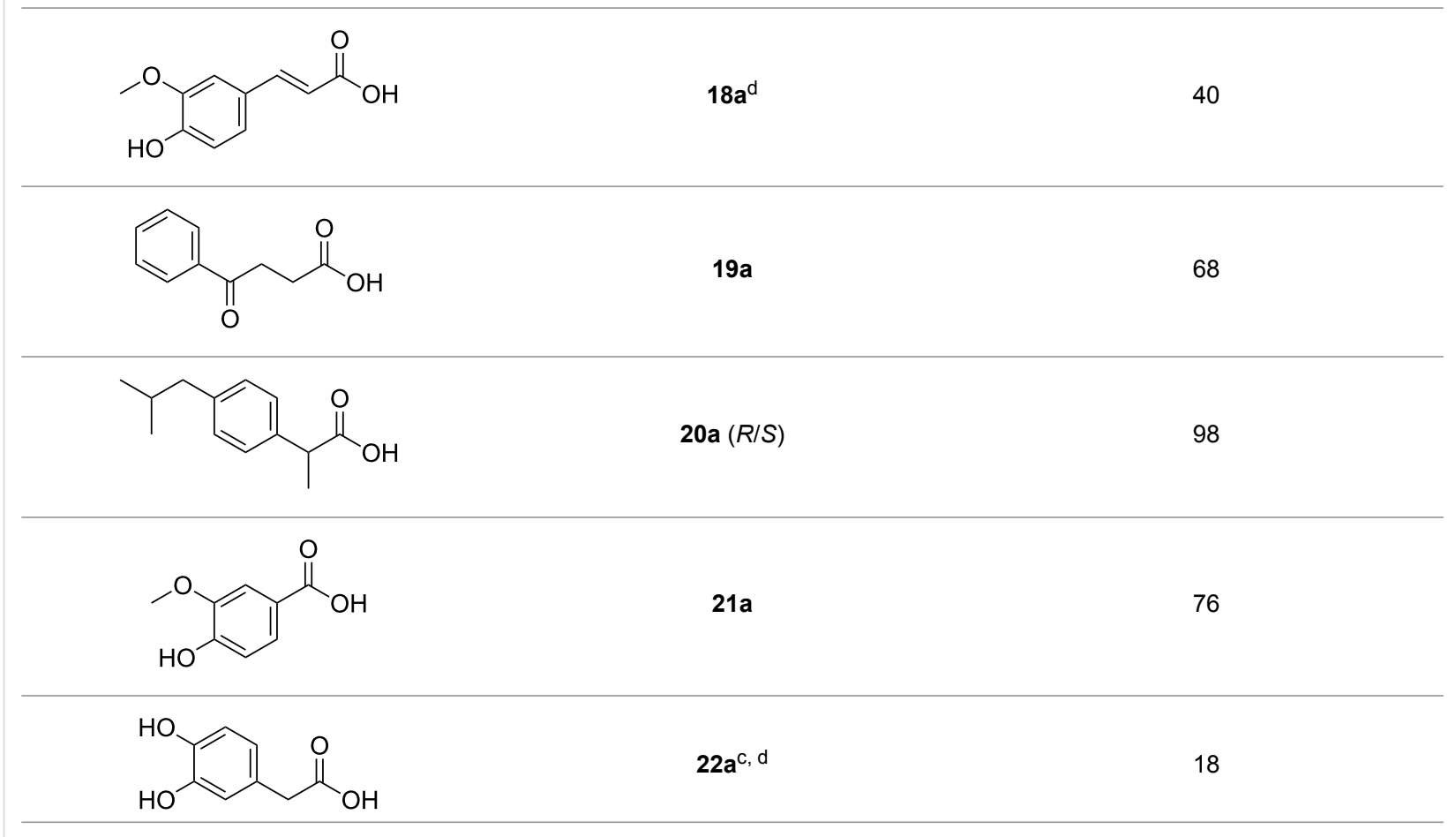

aReaction conditions: Tris- $\mathrm{HCl}$ buffer $\left(1 \mathrm{~mL}, 100 \mathrm{mM}, \mathrm{pH}\right.$ 9) contained NADP ${ }^{+}(0.9 \mathrm{mM}), \mathrm{GDH}(1 \mathrm{U})$, glucose $(60 \mathrm{mM}), \mathrm{MgCl}_{2}(10 \mathrm{mM}), \mathrm{ATP}(15 \mathrm{mM})$, substrate concentration ( $10 \mathrm{mM}$ ) and enzyme mixture (holo-CAR, $50 \mathrm{ug}$ ), $16 \mathrm{~h}, 25^{\circ} \mathrm{C}, 200 \mathrm{rpm}$. bSame as a , but $5 \mathrm{mM}$ of substrate and $100 \mu \mathrm{g}$ of Mycobacterium CAR were used. 'Same as ${ }^{\text {a }}$, but the reaction was performed in sodium phosphate buffer (100 mM, pH 7.5). ${ }^{\mathrm{d}}$ Silylation was performed before the GC analysis.

and 1a, respectively. This may be due to the sterically hindered effect of the $\alpha$-methyl substitution, which is consistent with the results for Pyrococcus furiosus (whole-cell) [36] and NiCAR
[31]. However, no significant difference was noted between 3-phenylbutyric acid (15a) and 7a. Mycobacterium CAR showed good chemoselectivity for the reduction of some 
carboxylic acids containing $\mathrm{C}=\mathrm{C}$ or $\mathrm{C}=\mathrm{O}$ double bonds, such as linoleic acid (16a), cinnamic acid (17a), ferulic acid (18a), and 3-benzoylpropionic acid (19a). These acids were reduced, with $\mathrm{C}=\mathrm{C}$ or $\mathrm{C}=\mathrm{O}$ double bonds remaining unaffected. However, this enzyme was less active toward 17a than its saturated counterpart (7a). Interestingly, Mycobacterium CAR could effectively reduce ibuprofen (20a) more effectively than NiCAR and SrCAR, but it was not enantioselective. Rac-13a, rac-14a and rac-15a $(5 \mathrm{mM})$ were almost completely transformed by Mycobacterium CAR $(100 \mu \mathrm{g})$, suggesting it had no or low enantioselectivity toward these compounds.

The Mycobacterium CAR-catalysed carboxylic acid reduction was combined with Wittig reaction to establish a new chemoenzymatic approach to the synthesis of $\alpha, \beta$-unsaturated esters. As described in the Experimental section, the holo-CAR enzyme mixture was prepared and mixed with $\mathrm{NADP}^{+}, \mathrm{GDH}$, glucose, ATP and carboxylic acid in Tris- $\mathrm{HCl}$ buffer. The reaction mixture was incubated at $25^{\circ} \mathrm{C}$ for $16 \mathrm{~h}$ and extracted with ethyl acetate. The organic extract was concentrated to about $20 \mathrm{~mL}$, and mixed with ethyl (triphenylphosphoranylidene)acetate and $\mathrm{Na}_{2} \mathrm{CO}_{3}$. After $24 \mathrm{~h}$ at room temperature, the organic solvent was removed under reduced pressure and the residue was purified by silica gel column chromatography to give the product ( $\alpha, \beta$-unsaturated ester). As shown in Table 3 , $\alpha, \beta$-unsaturated esters were obtained in moderate to high yields with trans-isomer as the major product. The corresponding $\alpha, \beta$ unsaturated esters from aromatic carboxylic acids (1a, 2a, 10a, 12a and 17a) had higher yields than those from aliphatic ones (3a, 4a and 5a), and this might be due to lower yields of aliphatic aldehydes and higher loss in the product separation.

\section{Conclusion}

A new CAR from Mycobacterium sp. was successfully cloned, overexpressed and identified. It exhibited a broad substrate spectrum and was active toward both aliphatic and aromatic carboxylic acids, including ibuprofen. Other functional groups such as keto groups and $\mathrm{C}=\mathrm{C}$ double bonds remained unaffected. Mycobacterium CAR catalysed carboxylic acid reduction to give aldehydes, followed by a Wittig reaction to afford $\alpha, \beta$-unsaturated esters with extension of two carbon atoms. This study demonstrates a new chemo-enzymatic chain elongation method for the synthesis of these important compounds from bio-based fatty and aromatic acids of natural resources. However, the enzymatic reduction of carboxylic acids requires CoA, ATP and NADPH, and this still presents challenge for its application at large scale, which may be overcome by using the whole cell catalyst of the engineered enzyme production strain with efficient amount of CoA, ATP and NADPH or effective regeneration systems of them.

\section{Experimental \\ Cloning of Mycobacterium CAR gene}

Mycobacterium sp. chromosomal DNA (gDNA) was extracted and purified using a TIANamp Bacteria DNA Kit. The Mycobacterium CAR gene (Gene ID 17912504) was amplified

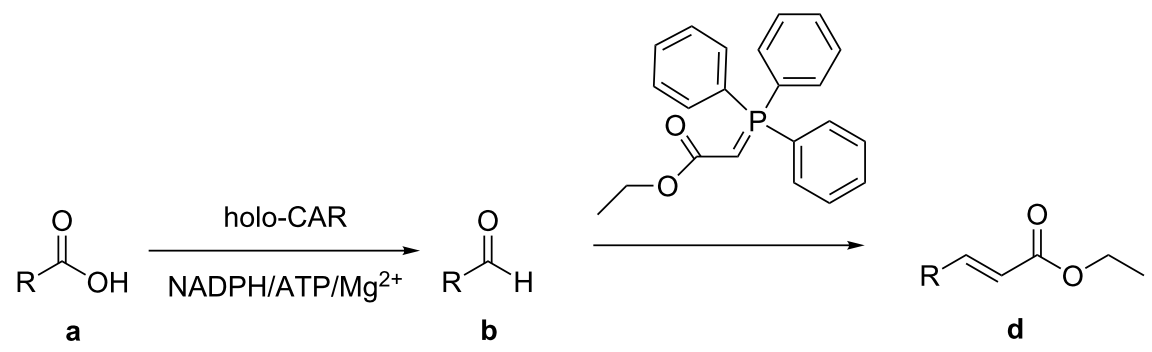

\begin{tabular}{|c|c|c|c|}
\hline Substrate (a) & Analytic yield (\%) of aldehydes $(\mathbf{b})^{\mathrm{b}}$ & Isolated yield (\%) of $\alpha, \beta$-unsaturated esters (d) & Ratio $E / Z^{C}$ \\
\hline $1 a$ & 72 & 60 & $68: 32$ \\
\hline $2 a$ & 100 & 70 & $92: 8$ \\
\hline $3 a$ & 65 & 41 & $87: 13$ \\
\hline $4 a$ & 70 & 46 & $89: 11$ \\
\hline $5 a$ & 67 & 38 & $96: 4$ \\
\hline $10 a$ & 100 & 81 & $92: 8$ \\
\hline $12 a$ & 79 & 59 & $90: 10$ \\
\hline $17 a$ & 78 & 65 & $94: 6$ \\
\hline
\end{tabular}

aThe carboxylic acid was first reduced to aldehyde, after being extracted with ethyl acetate, ethyl (triphenylphosphoranylidene)acetate was added for the Wittig reaction. ${ }^{\mathrm{b}}$ Determined by GC analysis of the reaction mixture. ${ }^{\mathrm{C}}$ Determined by GC analysis of isolated products. 
by PCR using Mycobacterium gDNA as template and primers containing the restriction sites $N d e \mathrm{I}$ and $\mathrm{XhoI}$, respectively, CAR-F 5'-CATGCATATGTTCGCCGAAAATCTTGATGACCAG-3' and CAR-R 5'-CATCTCGA GCAGCAGGCCGAGCAATTGCAGGT-3'. The PCR fragment was purified and then ligated with cloning vector pJET1.2/blunt, which was confirmed by DNA sequencing. A CAR DNA fragment was acquired from the vector pJET1.2-CAR by digesting at the restriction sites NdeI and XhoI, and then ligated by T4 DNA ligase into $\mathrm{pET} 30 \mathrm{~b}(+)$ at the same restriction sites to generate the expression vector pET30b(+)-CAR. The confirmed recombinant vector was transformed into E. coli BL21(DE3).

\section{Expression and purification of Mycobac- terium CAR and Nocardia PPTase}

A culture of E. coli BL21 (DE3) cells harboring pET30b(+)CAR or pET32a(+)-PPTase was grown overnight in LB-ampicillin $(100 \mu \mathrm{g} / \mathrm{mL})$ medium $(5 \mathrm{~mL})$ at $37{ }^{\circ} \mathrm{C}$, and then inoculated into $1 \mathrm{~L}$ of LB-ampicillin $(100 \mu \mathrm{g} / \mathrm{mL})$ medium. The resulting culture was incubated continually at $200 \mathrm{rpm}$ in a rotary shaker at $37{ }^{\circ} \mathrm{C}$ until cells reached mid-log growth $\left(\mathrm{OD}_{600}\right.$ of $\left.0.5-1.0\right)$, which was followed by the addition of $0.5 \mathrm{mM}$ IPTG and further incubation for $12 \mathrm{~h}$ at $25^{\circ} \mathrm{C}$. Cells were harvested by centrifugation at $12000 \mathrm{~g}$ for $10 \mathrm{~min}$ at $4{ }^{\circ} \mathrm{C}$, and disrupted by high pressure homogenizer after re-suspension in binding buffer ( $20 \mathrm{mM}$ sodium phosphate buffer, $0.5 \mathrm{M}$ $\mathrm{NaCl}, 20 \mathrm{mM}$ imidazole, $\mathrm{pH}$ 7.4). His-CAR or His-PPTase protein in the supernatant fraction was collected from the crude cell lysate by centrifugation at $12000 \mathrm{~g}$ for $20 \mathrm{~min}$. Protein purification was performed on a HisTrap ${ }^{\mathrm{TM}} \mathrm{FF}$ crude column (GE Healthcare, Piscataway, USA), and the protein was desorbed with an elution buffer $(20 \mathrm{mM}$ sodium phosphate, $0.5 \mathrm{M} \mathrm{NaCl}, 0.5 \mathrm{M}$ imidazole, $\mathrm{pH}$ 7.4). The purified proteins His-CAR or His-PPTase were dialyzed in a sodium phosphate buffer $(50 \mathrm{mM}, \mathrm{pH} 7.5)$ and then stored at $-20^{\circ} \mathrm{C}$ for further use.

\section{Standard reduction procedure}

The His-CAR (1.3 mg) was incubated with His-PPTase $(256 \mu \mathrm{g})$ in the presence of CoA $(1 \mathrm{mM})$ as a cofactor for $1 \mathrm{~h}$ at $28{ }^{\circ} \mathrm{C}$ in a final volume of $520 \mu \mathrm{L}$ of sodium phosphate buffer (100 mM, pH 7.5) containing $10 \mathrm{mM}$ of $\mathrm{MgCl}_{2}$. The resulting enzyme mixture (holo-CAR, 50 or $100 \mu \mathrm{g}$ ) was mixed with $\mathrm{NADP}^{+}(0.9 \mathrm{mM}), \mathrm{GDH}(1 \mathrm{U}$, one unit corresponds to the amout of enzyme which could convert $1 \mu \mathrm{mol} \mathrm{NADP}{ }^{+}$to NADPH per minute using D-glucose as the substrate), glucose (60 mM), $\mathrm{MgCl}_{2}(10 \mathrm{mM})$, carboxylic acid (5 or $10 \mathrm{mM}$, from $1 \mathrm{M}$ stock solution in DMSO), and ATP $(15 \mathrm{mM})$ in Tris- $\mathrm{HCl}$ buffer (100 mM, pH 9) with a final volume of $1 \mathrm{~mL}$. The reaction mixture was incubated at $200 \mathrm{rpm}$ in a rotary shaker at $25^{\circ} \mathrm{C}$ for $16 \mathrm{~h}$, and extracted with $1 \mathrm{~mL}$ of ethyl acetate after the $\mathrm{pH}$ was adjusted to $2-3$ with $1 \mathrm{M} \mathrm{HCl}$ solution. The organic extracts were dried over anhydrous sodium sulfate and analysed by gas chromatography (GC) to determine the amount of substrate (a) and products (aldehyde b) in the mixture. All experiments were conducted in triplicate.

\section{Substrate specificity}

The reduction of a series of carboxylic acids was carried out by following the standard reduction procedure. The yields were determined by GC analysis.

\section{Experimental procedures for the synthesis of compounds $\mathbf{1 d}, \mathbf{2 d}, \mathbf{3 d}, \mathbf{4 d}, \mathbf{5 d}, \mathbf{1 0 d}, \mathbf{1 2 d}$ and 17d}

A typical procedure was as follows using ethyl 4-phenylbut-2enoate (1d) as the example. The enzyme mixture (holo-CAR, $0.5 \mathrm{mg} / \mathrm{mL}$ ) was prepared as described above, and was mixed with $\mathrm{NADP}^{+}(0.45 \mathrm{mM})$, GDH (1 U), glucose $(60 \mathrm{mM})$, ATP $(13 \mathrm{mM})$ and phenylacetic acid $(\mathbf{1 a}, 10 \mathrm{mM})$ in Tris- $\mathrm{HCl}$ buffer (total volume $25 \mathrm{~mL}, 100 \mathrm{mM}, \mathrm{pH} 9$ ). The reaction mixture was incubated at $100 \mathrm{rpm}$ in a rotary shaker at $25^{\circ} \mathrm{C}$ for $16 \mathrm{~h}$, and extracted 3 times with $25 \mathrm{~mL}$ of ethyl acetate. The organic extract was concentrated to about $20 \mathrm{~mL}$ under reduced pressure, and then ethyl (triphenylphosphoranylidene)acetate $\left(100 \mathrm{mM}\right.$ ) and $\mathrm{Na}_{2} \mathrm{CO}_{3}$ (about $0.5 \mathrm{~g}$ ) were added, and the reaction mixture was stirred for $24 \mathrm{~h}$ at room temperature. The organic solvent was removed under reduced pressure and the residue was purified by silica gel column chromatography to give the product, 1d (30.1 $\mathrm{mg}, 60 \%)$ was obtained.

\section{Supporting Information}

\section{Supporting Information File 1}

Materials, bacterial screening, analytical procedures, NMR data and spectra of $\mathbf{1 d}, \mathbf{2 d}, \mathbf{3 d}, \mathbf{4 d}, \mathbf{5 d}, \mathbf{1 0 d}, \mathbf{1 2 d}$ and $\mathbf{1 7 d}$. [http://www.beilstein-journals.org/bjoc/content/ supplementary/1860-5397-11-243-S1.pdf]

\section{Acknowledgements}

This work was financially supported by National Basic Research Program of China (973 Program, No. 2011CB710800) and the Chinese Academy of Sciences (KSZD-EW-Z-015).

\section{References}

1. Shibata, K.; Chatani, N. Org. Lett. 2014, 16, 5148-5151. doi:10.1021/ol502500c

2. Cheng, J.; Huang, Z.; Chi, Y. R. Angew. Chem., Int. Ed. 2013, 52, 8592-8596. doi:10.1002/anie.201303247

3. Wang, P.; Ling, L.; Liao, S.-H.; Zhu, J.-B.; Wang, S. R.; Li, Y.-X.; Tang, Y. Chem. - Eur. J. 2013, 19, 6766-6773. doi:10.1002/chem.201204182 
4. Hashimoto, T.; Maruoka, K. Chem. Rev. 2015, 115, 5366-5412. doi:10.1021/cr5007182

5. Zhu, Y.; Wang, Q.; Cornwall, R. G.; Shi, Y. Chem. Rev. 2014, 114, 8199-8256. doi:10.1021/cr500064w

6. He, J.; Ling, J.; Chiu, P. Chem. Rev. 2014, 114, 8037-8128. doi:10.1021/cr400709j

7. Yasukawa, T.; Suzuki, A.; Miyamura, H.; Nishino, K.; Kobayashi, S. J. Am. Chem. Soc. 2015, 137, 6616-6623. doi:10.1021/jacs.5b02213

8. Weber, F.; Brueckner, R. Eur. J. Org. Chem. 2015, 2428-2449. doi:10.1002/ejoc.201403622

9. Peacock, L. R.; Chapman, R. S. L.; Sedgwick, A. C.; Mahon, M. F.; Amans, D.; Bull, S. D. Org. Lett. 2015, 17, 994-997. doi:10.1021/acs.orglett.5b00103

10. Niu, Z.; Chen, J.; Chen, Z.; Ma, M.; Song, C.; Ma, Y. J. Org. Chem. 2015, 80, 602-608. doi:10.1021/j05021135

11. Parveen, S.; Hussain, S.; Qin, X.; Hao, X.; Zhu, S.; Rui, M.; Zhang, S.; Fu, F.; Ma, B.; Yu, Q.; Zhu, C. J. Org. Chem. 2014, 79, 4963-4972. doi:10.1021/j0500338c

12. Hatano, M.; Horibe, T.; Ishihara, K. Angew. Chem., Int. Ed. 2013, 52, 4549-4553. doi:10.1002/anie.201300938

13. Časar, Z.; Steinbücher, M.; Košmrlj, J. J. Org. Chem. 2010, 75, 6681-6684. doi:10.1021/jo101050z

14. Oliveira, M. E. R.; da Silva Filho, E. C.; Filho, J. M.; Ferreira, S. S.; Oliveira, A. C.; Campos, A. F. Chem. Eng. J. 2015, 263, 257-267. doi:10.1016/j.cej.2014.11.016

15. Nakagiri, T.; Murai, M.; Takai, K. Org. Lett. 2015, 17, 3346-3349. doi:10.1021/acs.orglett.5b01583

16. Liu, J.; Liu, Q.; Franke, R.; Jackstell, R.; Beller, M. J. Am. Chem. Soc. 2015, 137, 8556-8563. doi:10.1021/jacs.5b04052

17. El-Batta, A.; Jiang, C.; Zhao, W.; Anness, R.; Cooksy, A. L.; Bergdahl, M. J. Org. Chem. 2007, 72, 5244-5259. doi:10.1021/jo070665k

18. Chen, Y.; Romaire, J. P.; Newhouse, T. R. J. Am. Chem. Soc. 2015, 137, 5875-5878. doi:10.1021/jacs.5b02243

19. Kona, J. R.; King'ondu, C. K.; Howell, A. R.; Suib, S. L. ChemCatChem 2014, 6, 749-752. doi:10.1002/cctc.201300942

20. Shearouse, W. C.; Korte, C. M.; Mack, J. Green Chem. 2011, 13, 598-601. doi:10.1039/c0gc00671h

21. Zeitler, K. Org. Lett. 2006, 8, 637-640. doi:10.1021/ol052826h

22. Kantam, M. L.; Kumar, K. B. S.; Balasubramanyam, V.; Venkanna, G. T.; Figueras, F. J. Mol. Catal. A: Chem. 2010, 321 , 10-14. doi:10.1016/j.molcata.2010.01.012

23. List, B.; Doehring, A.; Hechavarria Fonseca, M. T.; Job, A.; Rios Torres, R. Tetrahedron 2006, 62, 476-482. doi:10.1016/j.tet.2005.09.081

24. Barma, D. K.; Kundu, A.; Bandyopadhyay, A.; Kundu, A.; Sangras, B.; Briot, A.; Mioskowski, C.; Falck, J. R. Tetrahedron Lett. 2004, 45 , 5917-5920. doi:10.1016/j.tetlet.2004.05.113

25. Maryanoff, B. E.; Reitz, A. B. Chem. Rev. 1989, 89, 863-927. doi:10.1021/cr00094a007

26. Seyden-Penne, J. Reductions by the Alumino-and Borohydrides in Organic Synthesis; Wiley-VCH: Weinheim, Germany, 1997.

27. Napora-Wijata, K.; Strohmeier, G. A.; Winkler, M. Biotechnol. J. 2014, 9, 822-843. doi:10.1002/biot.201400012

28. Duan, Y.; Yao, P.; Chen, X.; Liu, X.; Zhang, R.; Feng, J.; Wu, Q.; Zhu, D. J. Mol. Catal. B: Enzym. 2015, 115, 1-7. doi:10.1016/j.molcatb.2015.01.014

29. Venkitasubramanian, P.; Daniels, L.; Rosazza, J. P. N. J. Biol. Chem. 2007, 282, 478-485. doi:10.1074/jbc.M607980200
30. He, A. M.; Li, T.; Daniels, L.; Fotheringham, I.; Rosazza, J. P. N. Appl. Environ. Microbiol. 2004, 70, 1874-1881. doi:10.1128/Aem.70.3.1874-1881.2004

31. Li, T.; Rosazza, J. P. J. Bacteriol. 1997, 179, 3482-3487.

32. Behrouzian, B.; McDaniel, R.; Zhang, X.; Clark, L. Engineered Biosynthesis of Fatty Alcohols. WO Patent WO2,010,135,624, Nov 25, 2010.

33. Akhtar, M. K.; Turner, N. J.; Jones, P. R. Proc. Natl. Acad. Sci. U. S. A. 2013, 110, 87-92. doi:10.1073/pnas.1216516110

34. Shtratnikova, V. Y.; Bragin, E. Y.; Dovbnya, D. V.; Pekov, Y. A.; Schelkunov, M. I.; Strizhov, N.; Ivashina, T. V.; Ashapkin, V. V.; Donova, M. V. Genome Announce. 2014, 2, No. 1e01177-13. doi:10.1128/genomeA.01177-13

35. Li, T.; Rosazza, J. P. J. Biol. Chem. 1998, 273, 34230-34233. doi:10.1074/jbc.273.51.34230

36. van den Ban, E. C. D.; Willemen, H. M.; Wassink, H.; Laane, C.; Haaker, H. Enzyme Microb. Technol. 1999, 25, 251-257. doi:10.1016/s0141-0229(99)00036-8

\section{License and Terms}

This is an Open Access article under the terms of the Creative Commons Attribution License (http://creativecommons.org/licenses/by/2.0), which permits unrestricted use, distribution, and reproduction in any medium, provided the original work is properly cited.

The license is subject to the Beilstein Journal of Organic Chemistry terms and conditions:

(http://www.beilstein-journals.org/bjoc)

The definitive version of this article is the electronic one which can be found at: doi:10.3762/bjoc. 11.243 